\title{
医薬品開発の現状と今後の課題
}

\section{特集 日本のトランスレーショナルリサーチをどう進めるか}

\section{齋藤宏暢・藤枝 徹・長沼英夫*}

Current status and issues of drug development strategy in Japan

Serious stagnation and low productivity in new drug discovery and development have been raised an alarm how the pharmaceutical industry can explore appropriate drug candidates and conduct efficient development as well as preventing drop-out at the later clinical stage. For this purpose, we must reconsider several empirical and stereotypical programs so far used in clinical development. Instead, the human based exploratory clinical study such as single micro dosing PK study campaigned by both US and European regulatory agencies might be one of powerful tools to ascertain the possibility "to go" or "not to go" at the earlier stage of drug development.

In order to improve traditionally insufficient subject enrollments only in domestic clinical trials, participation in multinational clinical trials will make possible an adequate evaluation of drug safety and efficacy through systematic comparison with foreign data. Further efforts should be paid to establish an infrastructure and circumstance to achieve this kind of clinical trials in Japan soon. We should also learn about how to manage the provisions of Japan own by referring not only clinically forward US and European countries but also Asian.

The ICH E2E-guided proactive post-marketing surveillances and clinical trials after approval might be important for understanding the details without consuming too much time as well as money at the R\&D stages.

新規医薬品の開発が全世界的に停滞している現状を鑑みると，適切な候補化合物をいかに効率よく 創製し，臨床 stage での中止リスクを軽減しつつ迅速に開発を進めるためにはどのような検証が必要 なのか, 長年にわたり拠り所としてきた半ば定型的な臨床開発プログラムについて真剣に見直す時期 にきている．たとえば，海外の規制当局で許容しているマイクロドージングのような探索的な臨床試 験は，創薬の初期段階で薬物動態特性を見極めるための有用なツールである.

また，これまで国内の臨床試験だけでは安全性と有効性を検証するうえで例数的に不充分な場合が 多かったが，国際共同治験への参加は海外デー夕を相互に利用することを可能とし，医薬品としての 特性を系統的に評価するうえできわめて重要であり，日本でもグローバル基準の臨床試験が出来るイ ンフラの早急な整備が必要である。この際, 症例がとりやすい欧米ばかりでなく，アジア各国の実施 動向を瞄みながら日本にあった参画条件を模索すべきである.

さらに，承認申請までの限られた評価に過度な時間と経費をかけるのではなく， ICH-E $2 \mathrm{E}$ ガイド ラインを考慮した製造販売後の調査や，臨床試験を通して幅広い患者に適用したときの安全性と有効 性を, 計画的に追加検証する施策が重要である.

Hironobu Saito · Toru Fujieda · Hideo Naganuma* key words : drug development, $\mathrm{CRC}$, micro-dosing, ICH, infrastructure

日本において ICH-GCP に基づく新しい GCP が 施行されてから 8 年が経つ.この新 GCP 施行に よって ICH のコンセプトである“より早く効率よ く世界の患者へ薬郕を届ける”という条件が制度上 は整うこととなった。しかしながら，旧 GCPから の大きな変更を余儀なくされたため, 現在において も国内では患者を使った治験の進行は他の ICH 参

\footnotetext{
* New Drug Development Division, Sankyo Co., Ltd. 三共株式会社 医薬開発本部
}

加諸国とくらべてパフォーマンスがわるく, 反面, 過剩なまでに試験の品質を追求するあまり臨床試験 自体のコスト高を助長し，ICH のコンセプトをい まだに達成できない状況である。

しかしながら, 最近になって治験を効率的に進 めるためのいくつかの具体的な施策が行政当局, 依 頼者側ならびに実施施設側で施行されてきている. CRO や SMO (site management organization : 実 施施設のサポートビジネス)という新しいビジネ 


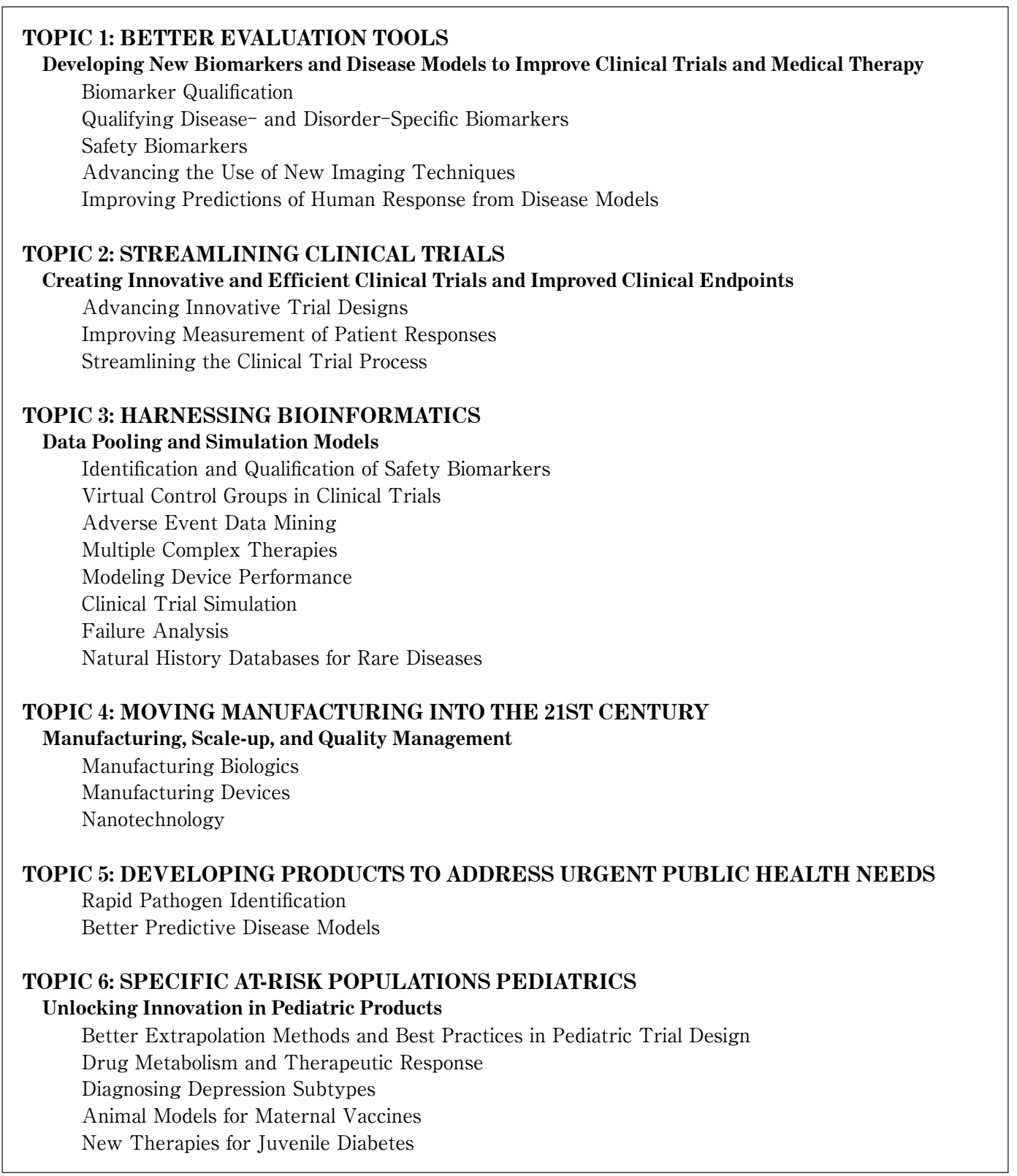

スがこれを後押しし，特に CRC (clinical research coodinator)の育成と治験における貢献は, 早く質 の高い治験が実施できる状況を生んできた。

また，当局から 2004 年 8 月 30 日に発表された “医薬品産業ビジョン”でも“創薬環境整備”が重 要な課題として示されたことは, 今後の臨床試験環 境を改革するうえで非常に重要なサポートになると 期待される ${ }^{1)}$.

本稿では，製薬企業の立場から主に国内での医薬 品開発の促進に向けた複数の施策について紹介し
たい.

\section{研究開発段階での双方向トランス レーショナルリサーチの活用}

2003 年にヒトゲノムの全配列の解読が完了し, 世はまさに“ポストゲノム”“ポストシーケンス” の時代にある。疾患原因となる遺伝子のゲノムワイ ドでの検索にはじまり，その産物である受容体や酵 素などのターゲット蛋白ならびに代謝物の構造と機 
能を分子レベルで特定することが可能となった．こ れと独立して, 遺伝子自体や蛋白質に高い活性で, かつ, 選択的に作用する生理活性分子の検索, いわ ゆる “hit of seeds”のための創薬システムは, い ずれの製薬企業においても複数のライブラリによる コンビナトリアル合成とハイスループットスクリー ニングを効率的にリンクさせた創薬プラットフォー ムとして確立してきている.


上述のようなライフサイエンスの革新的マイルス トンが達成され基盤技術として導入されているにも かかわらず，かねてからゲノム情報の最も有効なア プリケーションとして期待されていた創薬について 目を向けると, あいかわらず数多くの医薬品候補が 第 II 相試験の段階で有効性を検証することが出来な い, あるいは, 副作用との乘離が出来ないなどの理 由によって開発の中断を強いられる事態に直面して いる.

このような状況分析を踏まえて, FDA は2006 年 に医薬品開発の停滞を脱却するための具体的なラ イフサイエンス技術を六つのトピックス領域に区 分し, 計 76 の事例 (未完成の技術も含む) を列挙し たCritical Path Opportunities Listを発行し, 産・ 官・学が協力してこれらの技術を積極的に駆使する ことにより, 医薬品ならびに医療機器開発の成功確 率の向上を図るよう提案している $\left(\right.$ 表 1 ${ }^{3)}$. なかで も, 最終エンドポイントの代償となる適切なバイオ マーカーの開発 (トピックス 1) と臨床試験の合理化 (トピックス 2)の二つは, 医薬品開発のうえで特に 優先すべき課題として強調されている.

さらに，開発を効率的に進めるためのプログラ ムとして, 従来よりも簡略化した非臨床の安全性 情報があれば適切な医薬品候補を絞り达む, ある いは開発の可能性について見極める目的で, 副作 用の眯念がない低用量でのヒトを使った臨床試験 (exploratory IND 試験, 以後 eIND 試験) が提供さ れている4).

FDA の eIND 試験ガイダンスは, 目的が異な る 2 通りの概念から構成されており, 開発する医 薬品候補の特性に応じて柔軟性を持たせている。 すなわち, 開発上懸念される薬物動態特性をいち
早く確認するための極低用量 (予想される臨床有 効用量の $1 / 100$ あるいは $100 \mu \mathrm{g}$ のうちの低值)で の単回投与でのマイクロドージング試験, およ び期待する臨床用量にまで至らない低用量 (subpharmacologic dose)に拈いて, 高感度なバイオ マーカーを追跡することで期待するべき薬郕反応 性 (pharmacodynamics) が得られるか否か確認する 最大 7 日間までの反復投与を許容した探索的な薬効 確認試験である。これらの臨床試験を実施するとき に求められる化合物の品質や非臨床毒性試験の基準 は目的によって異なり, また, 個々の候補化合物ご とにデータを揃える必要はあるものの, ガイダンス は最大で 5 化合物までの一連の候補化合物を一つの eIND 試験のなかで検討することを許容しており， 開発を進めるべき医薬品候補の選択にも利用するこ とが出来る.

ヨーロッパでもアメリカと類似した考え方と規 制のもと, 探索的な臨床試験を後押しする環境が整 備5)されているが, こと日本においては規制当局側 の対応がいまだなされていない.一方で, 薬剤反応 性の民族差をいち早く理解しグローバル開発を促進 させるため, 日本人あるいはアジア人でのマイクロ ドージング試験の必要性の議論, ならびに, 既承認 薬を使った具体的な実施可能性についての検討がは じまっている ${ }^{6,7)}$.

このような新たな技術や評価系を開発に積極的に 取り入れ，よりよい医薬品を効率的に開発するうえ で肝心な視点としては，たんに eIND 試験のような “探索 $\rightarrow$ 臨床”方向の検討にとどまらず，“臨床 $\rightarrow$ 探 索”方向，すなわち双方向からのトランスレーショ ナルリサーチが必要となる.

たとえば, 新薬として世に出され, 何百万人, 何千万人もの患者に広く適用されて, はじめて治 験段階でみられなかった重篤な副作用がみられるこ とがある.もしこの副作用が安全性上看過すること が出来ない頻度で発生する場合は, 薬剤のリスク・ ベネフィットを考慮し余儀なく市場からの撤退を決 断しなくてはならないケースがある。典型的な事 例として, 数万例に 1 例程度ではあるものの重篤な 肝障害を発症するために, 2000 年に販売が中止さ れた糖尿病治療剤トログリダゾンがあげられる。当 
時は DNA 検体のバンキングの概念もなく, 副作用 の原因を解明する環境が未成熟であったため患者の 事後追跡や血液検体の取得に苦慮したが，25例の 患者で行った事後的な遺伝子解析によってグルタチ オ $\mathrm{S}$ 転移酵素(GST)の遺伝子多型が副作用の一因 となる可能性が示された ${ }^{8)}$. 以後, 同系の医薬品候 補を新たに探索する際は, この仮説に基づき代謝過 程に GST が関与しないような分子設計をすること を基本方針として研究を進めるための足掛かりにも なった。

今後, first-in-class の薬剤や患者の特異体質 (idiosyncrasy)による副作用が想定される薬剤につ いては, 製造販売後の使用追跡調査や臨床試験など 継続的な育薬プログラムのなかで, DNA 検体のバ ンキングを含めて有害事象発生時に詳細な事後解析 を実施できる体制を産・官が協力しつつ確立してい くとともに, 国民に対してはゲノム創薬と遺伝薬理 学が 21 世紀の医療の根幹としてきわめて重要であ ることを適宜啓蒙していく必要があろう.

\section{医薬品産業ビジョンと各国の施策}

“医薬品産業ビジョン”では, (1) グローバルな競 争力をつけること, (2) 不充分な創薬環境を改善す ること, (3) 悪化する医療保険財政を改善すること が課題として示されている. 特に(2)では, 治験の状 況が大きく取り上げられており, わが国の治験は遅 い, 質がよくない, 費用が高いことが課題であり, その理由として患者, 実施研究者のインセンティブ が低いこと, 治験の実施体制が弱いことが示されて いる.

イギリスやシンガポールなどの資源のそしい他 国では治験をビジネスとして考え, 海外から臨床 試験の実施を誘致する施策を行っている，イギリス では，スコットランド地方の造船不況を克服するた め, 治験における第 I 相試験に入るハードル（特に 毒性試験)を下げ，第 I 相試験を中心とした治験ビ ジネスを推進した。グローバル企業や日本の企業も 第 I 相試験をイギリスで行うことがトレンドにも なった. シンガポールでは, 5,6 年前のアジア危 機以降ライフサイエンス事業を推進することとし,
当局 (Health Sciences Authority)が学会で宣伝活動 を行っている。また, Clinical Research Centreを 企業と合弁での設立やマレーシア中心で行われる Asian-CTD (統一の申請資料)に積極的に貢献して いる. シンガポールヘアジアの head office を移す グローバル製薬企業も出てきている. 臨床試験も “global clinical trial except Japan”という考え方も 議論されるようになり, 日本のインフラ整備はたい へん critical な問題となっている.

臨床試験を実施するインセンティブは, 新薬開発 を実施するうえで新しい治療方法を体験できること や，学会発表や論文投稿がその結果を報告すること で容易であることなどがあげられる，プラバス夕チ ンは日本にて開発が進行した薬剤の一例であるが, phase I 試験結果はJAMA に掲載されている.

しかし，いまのままでは，国内企業もインフラ 整備が出来ている海外で開発をはじめる可能性が高 い. 国内を拠点とする企業としては日本のビジネス も重要であり, ビジネスの観点以外からも日本国内 の医療福祉に積極的に貢献することを強く望んでい る. そのためにも日本人のデータをグローバル基準 で評価する日本の治験施設のインフラ整備は非常に 重要である.

\section{インフラ整備の現状と大規模治験ネットワーク}

“全国治験活性化 3 力年計画”における, 日本の 施設インフラ整備のなかで “大規模治験ネットワー ク”は一番に位置されている. 大規模治験ネット ワークの意義として(1) クリニックの参加, (2) IRB (治験審査委員会)の共同開催の二つがあげられる.

\section{1. クリニックの参加}

現在, 病院とクリニックとの連携を強化し, 個々 の患者に則した治療を行おうという試みがなされて いる.これはコア病院を中心にクリニックや小病院 とのネットワークを構築するものであり, 専門的な 治療が可能な病院と患者に則した治療提供が出来る クリニックの利点をうまく利用することを目的とす る.この相補的システムを治験に利用するという試 みである. 
クリニックや小病院では対応できない IRBや重 篤な有害事象対応をコア病院に相当してもらい，ま た，担当医師の教育や治験の進渉管理を行ってもら う. その代わりに, 糖尿病, 高血圧, 高脂血症など の生活習慣病や，インフルエンザ，ヘルペスなどの 急性疾患など，相対的に軽症の患者へ治験参加を広 く呼びかけることが可能となる。一般に, 上記生活 習慣病などの治験に適当な患者はクリニックに多く 来院されており，より早く患者を集めることが可能 となる。この場合のコア病院における CRC の重要 性はより増すこととなる。

\section{IRB の共同化}

現在の日本で施行されている GCP はもちろん ICH-GCP に基づいて作成されている. しかし, そ のなかで異なっている点は, 契約者が ICH-GCP で は治験責任医師であるのに対し, 日本では施設の長 である点である。このように変更した理由として は，日本においては個別の医師との契約だけでは， 重篤な有害事象など，なにか起こった場合の対応や 責任が充分に果たせないとの懸念により, 施設の長 としたと想像される。

一方，このように施設の長としたことで，各施 設にIRB が容易に設置できる状況ができ，これを 基本とする治験体制の構築に寄与したと思われる.

依頼者側としても，施設の長からの指示により IRB が容易に設置されたためにスムーズな対応を受ける ことが出来た。

しかしながら，このことは，逆にIRB を共同で 行うという考え方の定着には不向きであったよう に思われる．施設の治験体制が整った現在の状況を 考えると, 効率やコスト削減を考慮したIRBの共 同化が重要な時期と考えられる.アメリカにおいて は, 15 年前の研究会においても 44 施設中の 42 施 設で共同IRB が開催されていた．その研究会は 2 日間行われ，1 日目は治験責任医師と study nurse が参加し薬剤の説明を行い, 2 日目はstudy nurse のみが残り症例記録の記載方法や試験方法の時系列 の手順の確認を行っていた。このような研究会は日 本で現在行われている進め方であり, 10 年ぐらい の遅れが日本にあるように推察される。
イギリスや香港では, IRB は地域(クラスター)ご とに存在し, 一つの地域で承認を受けると他の地域 での審査の軽減に繋がり，その国の全域にわたる 病院の審議が簡素化される方法をとっている. 特に IRB 間が相互認証 (MRP) 制であるため, 責任分担 が明確である。

日本での臨床試験ではペーパーワークが大変多 く，また，コンタクトパーソンも治験責任医師, $\mathrm{CRC}$, 薬剤部, 事務と多いため, 院内書類まで多 くなっている。 そのため, モニターは実施開始から 書類のやりとりに奔走することとなり, 症例記録の 記載確認がややもすると試験終了時になってしま う.このため, book タイプ(試験開始から終了まで の情報を一つの症例記録に記載するタイプ)の症例 記録が採用されることになっている.

一方, アメリカ, 東ヨーロッパ, シンガポール, 香港では, 1 カ月 1 回のモニタリングを行い, CRC に丸 1 日にわたって対応してもらえるため, 1 力 月間のデータを必ず source document verification (SDV：原資料と症例記録のチェック)するような 手順が可能となっている。このため, visit タイプ(1 回の検査ごとに回収する夕イプ）の症例記録が適当 となる。どちらの進め方が精度が高いかを比較する と, より最新情報の確認が出来ることやデー夕固定 をより早く出来ることから後者であることは間違い ない，したがって，ペーパーワークを削減すること は非常に重要となる。

IRB の共同化は, 試験全体の IRB 対応を削減で きる点でモニター業務削減に重要である。各 IRB では 20 近い資料作成が依頼者側で作成されるため, その作業も大きな業務となっている。また, 治験責 任医師の書類作成も, 現在はモニターがアポイント をとって入手していることから, 特に個々の医師の 履歴や印鑑など施設側の資料作成を CRC に担当し てもらえば，モニター業務の削滅となる。このよう な業務量が減れば, 重篤な有害事象対応やデー夕信 頼性確認などの本来の重要な業務に集中できること となる.

以上より, IRB の共同化を可能とするために，大 規模治験ネットワークの構築は重要と考えられる. 


\section{3. 今後の治験体制}

シンガポールや香港では, 電子カルテの各病院 への設置が完了している. 特に香港では, hospital authority clinical management system という当局 が中心となった統一したシステムが構築されてお り, 各病院のカルテを別の病院でも検索することが 可能となっている.このため, 治験に参加した患者 が他院に来院した場合でもこのシステムにてカルテ をみるため, アラームが出るシステムとなってい る.このシステムは初診料チェックなど医療費抑制 が元来の目的であるが, 治験でも充分活用可能なシ ステムである。目本においては，セキュリティーの 問題が大きく，また文化の違いによりこのようなシ ステムの導入が容易ではないのが実態である.

このような状況を考慮すると, 日本では電子力 ルテでの統一には時間がかかるため, 保険証や診察 券の統一や IT 化が一つの突破口になるかもしれな い.

\section{4. 各国のインフラ整備}

南アメリカや東ヨーロッパ・アジア各国では, 施 設のインフラを強化している病院が多く存在する. グローバル医薬品メーカーや $\mathrm{CRO}$ が各地域病院と タイアップしてインフラ整備を行っている. 特に 対応が進んでいるのは IRB 設置と治験責任医師や CRC の教育である. 彼らは施設インフラを行った あとに治験を行い, FDAの查察を積極的に受け入 れ，“適”評価をもらうことでインフラ整備を完結 している. FDAの査察では, 特にグローバルメー カーや CRO に頼って進めていないかどうかを治験 責任医師や CRC にインタビューすることが重要で あり，すなわち関与している関係者の GCP の知識 の確認が重要のようである.

治験施設のインフラ整備は, 治験責任医師, $\mathrm{CRC}$ の教育を中心に行う必要があり, コア病院での 教育システムが今後ますます重要になると思われる.

\section{今後の開発戦略}

\section{1. 国際共同治験への積極的な参加}

欧米巨大製薬企業の臨床試験においては, 一層
のスピードアップを目的とした南アメリカや東ヨー ロッパ, さらには中国, 韓国, 台湾, シンガポール といったアジアの施設も追加した国際共同治験が主 流となってきている. 中国, 韓国では年間 50１00 に近いグローバル試験が行われており，アジア各国 が国際共同治験のノウハウおよび経験を積んでいる のが現状である。

2006 年 8 月時点で，日本をプロトコールに含む 国際共同治験はわずか 6 件にとどまっており，経 験が豊富なアジア各国から大幅な遅れをとってい る ${ }^{9)}$. せっかくインフラが整っても他国での臨床試 験の再試しか出来ない状況となっており, ICH3 極 の 1 極を担っている日本としては由々しき状況であ る.

問題は国際共同治験への参画条件である。日本 に㧍ける参画条件については，いままで ICH など の活動で大枠は議論されてきたが, 具体的な対応に ついては各社ごとの当局との折衝のみに依存してお り, 大局的見地からの議論は少なかったように思わ れる。

上記に示した南アメリカ, 東ヨーロッパ, アジア 各国では, 欧米での前相までのデータがあればつぎ の相への参加が可能である. また, 中国, 韓国, 台 湾ではその国での臨床試験実施が承認条件となって いるが, 参加した国際共同試験のデータの転用が可 能である。このような制度はグローバル企業に対す る国際共同試験の誘致策の意味合いが強くビジネス 化しているとの批判もあるが, 各国の臨床試験のレ ベルを上げることに寄与している.

日本において医薬品産業を活性化するためには, 症例がとりやすい欧米ばかりでなく，アジア各国の 実施動向を睨みながら日本にあった参画条件を模索 すべきである。そのような状況のなかで患者におけ る $\mathrm{PK} / \mathrm{PD}$ 確認試験の重要性が高まっている.

$\mathrm{PK} / \mathrm{PD}$ 試験は， $\mathrm{EBM}$ を主張するための定量的 なデータを系統的に入手できるメリットがあり, 薬 物動態とバイオマーカーを駆使した代償的な薬効と の相関性や患者背景の影響などを明らかに出来るば かりでなく, 海外データ外挿のッールや非臨床デー タとの橋渡しとして検証的試験 (phase III) とともに 医薬品評価の中心的な位置づけとなってきている. 
患者への倫理的配慮を克服できるのであれば，薬剤 によっては国際共同治験への参画の条件として, 患 者における $\mathrm{PK} / \mathrm{PD}$ 試験を中心に置いた開発戦略も けっして無理なものではない.

また，開発時から市販後の対応を計画するとい うコンセプトを持つ E $2 \mathrm{E}$ ガイドラインは，いまま での経験から日本で特に検討すべき内容と思われ る ${ }^{10)}$. イレッサやノスカールのような市販後直後に 発生した安全性の問題を考えると, 市販後の安全性 デー夕を計画的に集約する施策が重要である，その ようなコンセプトをべースにすることにより，E5 ガイドラインに基づく海外デー夕利用を模索すべ きである. 特に欧米人とアジア人との ethnic factor の違いが薬効毒性に寄与する場合, 日本人と ethnic factor の近いアジア人との共同試験の重要性が高ま る.

\section{2. 臨床試験デザインの工夫と効率化}

臨床試験のデザインは, 実施に先立って充分な検 討がなされる。これまでの臨床試験は, 前相までに 得られた情報または類薬の情報に基づいて, 目標症 例数, 選択・除外基準, エンドポイント, アーム数 など必要な条件を決定し, 確固たるプロトコールと し記録したうえで試験が実施される。また，予期し なかった副作用が多発するなど, 倫理的あるいは社 会的に問題となる事態が発生しないかぎり, 当初に 計画した例数に到達するまで試験を終了することは 原則として許されていない.これは医薬品の臨床評 価では歴史的に Neyman-Pearson 流の統計学を基 本にしており, 事前に定めた計画に従って得られた データに基づいて判断することを重要視しているこ とによる.

一方で，最近 adaptive designs という考え方が 注目されている ${ }^{11)}$. Adaptive designs とは, 試験実 施の途中で試験デザイン (目標症例数, 選択・除外 基準, エンドポイント, アーム数など)を必要に応 じて変更したり, 試験の中止あるいは継続の判断を したりするデザインの総称であり, 基本的な考え方 は事前に不確かであった情報を試験途中の観測デー 夕を用いて再推定することによって, より効率的に 試験を実施しようという考えに基づくものである.
Adaptive designs は,これまでがんなど治療毒性 の強い疾患領域を中心に用いられてきた。近年, 海 外, 特にドイツにおいて, より多くの臨床試験で適 用されはじめ, 欧米では新たな臨床試験の手法とし て大いに注目されている。

Adaptive design の大義名分は, 薬効が不充分で 開発意義が見いだせないような医薬品候補につい ては早い段階で開発を中止でき, 必要以上に被験 者数を増さないため倫理面で大きなメリットがある こと, 不確実な情報に基づく試験計画の拙さを補う ことができ，よい医薬品を効率的に早く開発できる ことなどである．被験者に対する倫理面の改善だけ でなく, 製薬企業側にとっても試験の成功確率の向 上, 開発期間の短縮, 開発コストの削減などの大き なメリットがあることが, 欧米での注目の高さの要 因と考えられる．また，企業側にとっても有効性は あるものの, 対照群に対する統計学的な優位性を言 及するには, 症例数が不足するといった場合に適宜 症例を追加し，試験の成功確率を向上できること， また, 開発期間の短縮や開発コストの削減できる点 でも大きなメリットがある.

しかしながら, 国内においては思惑や恣意を除外 し客観的にデータを確認し, 試験自体が所期の方向 で進んでいるか否か検証するための独立データモニ タリング委員会の経験がそしく, なかなか普及しな いのが現状である.

今後は, adaptive designs の適用も視野に入れた 国際共同試験の実施が増えてくると予想されるが, 試験デザインを途中で変更することでデータの信頼 性が損われるとの懐疑的な意見もあり, 実際に活用 するためにはさらなる議論が必要であろう.

\section{まとめ}

医薬品産業を育成し, 日本の患者に最先端の治 療を速やかに提供するためには, 探索的な臨床試験 やなんらかの安全性が懸念される場合には, 患者背 景を考慮した事後的な遺伝子解析などを含めて, グ ローバルな基準での臨床試験を効率的に実施するイ ンフラの整備(たとえば, ガイダンス, 指針, 治験 実施施設, DNA 検体のバンキング)，ならびに治 
験や付随したトランスレーショナルリサーチの必要 性について国民の意識の高揚を図る必要がある。こ のうえで，アジア各国の試みを参考にしつつ，日本 の風土にあった大規模治験ネットワークシステムの 構築は重要である. 特にIRBの共同化は今後重要 なポイントと思われる.

日本でもインフラ整備が整いつつある昨今, “よ りよい薬剤をより早く”という ICH の概念に則り, 日本発で世界に先駆けて日本ではじめて承認された 薬剤を病気で苦しむ日本の患者にいち早く届けるべ く, 治験依頼者, 実施施設, 受託会社, および審査 側が，お互いの立場を真摰に理解し合い，さまざま な観点から critical pathの克服を目的とした透明性 の高い議論を行い, 一丸となって改革に邁進すべき である。

\section{文 献}

1）新木一弘, 中村直子：日本の治験の現状と課題. 薬事 48 : 1853-1856, 2006.

2) Innovation or Stagnation, Challenge and Opportunity on the Critical Path to New Medical Products. FDA, March 2004.

3) Critical Path Opportunities Report and List. FDA, March 2006.

4) Guidance for Industry, Investigators, and Reviewers Exploratory IND Studies. FDA, January 2006.

5) Position paper on non-clinical safety studies to support clinical trials with a single microdose. European Medicines Agency, June 2004.

6）杉山雄一, 大野泰雄・他：マイクロドーズ臨床試験の実施基 盤. 臨床評価 33(3)：649-677, 2006.

7）熊谷雄治, 杉山雄一・他：マイクロドーズの手法を用いた臨 床薬理試験. 第 54 回質量分析総合討論会講演要旨集, 2006 年 5 月.

8) Watanabe I, Koga T et al. : A study to survey susceptible genetic factors responsible for troglitazone-associated hepatotoxicity in Japanese patients with type 2 diabetes mellitus. Clin Pharmacol Ther 73(5) : 435-455, 2003.

9）石橋慶太：日本を含む国際共同治験実施状況一米国国立医 学図書館治験登録簿を用いた調査一. 医薬品産業政策研究所 ニュース 21(10)：18-21, 2006.

10）川原 章, 成川 衛: 新薬承認審査を取り巻く最近の情勢に ついて. 医薬品研究 $37: 268-277,2006$.

11) Bauer P, Einfalt J : Application of adaptive designs - A review. Biometrical Journal 48: 493-506, 2006. 